\title{
RANCANG BANGUN APLIKASI PENJUALAN DAN JASA SERVICE PADA SHOWROOM EXPO YAMAHA MOTOR DI KOTA PERDAGANGAN KABUPATEN SIMALUNGUN
}

\author{
Ilham Alfaridzi ${ }^{1}$, Dedi Suhendro ${ }^{2}$, Iqbal Sanjaya ${ }^{3}$ \\ ${ }^{1,2,3}$ Program Studi Komputerisasi Akuntansi \\ AMIK Tunas Bangsa, Pematangsiantar \\ Jl. Jend. Sudirman Blok A No.1-3 Pematangsiantar, 21127 \\ e-mail : ialfaridzii@gmail.com, dedi.su@amiktunasbangsa.ac.id, \\ Iqbal Sanjaya @ gmail.com
}

\begin{abstract}
Motorbikes are motorized vehicles that have two wheels. in a straight line lined up so that when the conditions go at high speed it remains stable because of the gyroscopic force. Moving at high speeds continues to run stable and at low speeds stability always depends on the settings. In Indonesia motorbike users are very popular because they are cheap, easy to reach, save fuel and the maintenance costs are not large. One of the most famous motorbikes in Indonesia is Yamaha with its founder from Japan named Yama Tarakusu. Yamaha motorbike is a service for consumers in providing motorized vehicle maintenance because it is designed by reliable experts. Yamaha Motor Trade Expo Showroom Simalungun Regency dealers selling motorcycles, spare parts while providing service services for consumer motorcycle vehicles have not been maximized and have not been satisfactory because they are still done manually on sales, especially in selling spare parts because there is no fast and accurate information regarding stock or inventory. In terms of service services, there is also no application system running at the Yamaha Motor Trade Expo Showroom in Simalungun Regency. The design of sales and service applications aims to facilitate and accelerate the sales data processing and motorcycle service, so that the administration of sales and information is faster and more accurate. Departing from this, the author designed the application of sales and service services at the Yamaha Motor Trade Expo Showroom in Simalungun Regency in the hope that sales applications and service services can provide fast, precise and accurate information.
\end{abstract}

Keywords : Sales, Motorcycle Services, Microsoft Visual Studio 2010, MySQL

\begin{abstract}
ABSTRAK
Sepeda motor merupakan kendaraan bermesin yang memiliki dua roda. dengan posisi lurus berbaris sehingga saat keadaan melaju dalam kecepatan tinggi tetap stabil karena adanya gaya giroskopik. Melaju dalam kecepatan tinggi tetap berjalan stabil dan pada kecepatan rendah kestabilan selalu bergantung pada pengaturan. Di Indonesia para pengguna sepeda motor menjadi sangat digermari karena harganya murah, mudah dijangkau, hemat bahan bakar dan biaya perawatannya tidak besar. Salah satu sepeda motor ternama di Indoensia adalah Yamaha dengan pendirinya berasal dari Jepang bernama Yama Tarakusu. Yamaha motor merupakan suatu layanan terhadap para konsumen dalam memberikan perawatan
\end{abstract}


kendaraan bermotor karena didesign oleh tenaga ahli yang handal. Showroom Expo Yamaha Motor Perdagangan Kabupaten Simalungun dealer penjualan sepeda motor, suku cadang sekaligus memberikan pelayanan jasa service kendaraan sepeda motor konsumen belum maksimal dan belum memuaskan karena masih dilakukan secara manual terhadap penjualan terutama dalam penjualan suku cadang karena tidak ada nya suatu informasi yang cepat dan akurat mengenai stok atau persediaan. Dalam hal pelayanan jasa service juga belum ada nya sistem aplikasi yang berjalan pada Showroom Expo Yamaha Motor Perdagangan Kabupaten Simalungun. Rancang bangun aplikasi penjualan dan jasa service ini bertujuan untuk memperlancar dan mempercepat proses pengolahan data penjualan dan jasa service sepeda motor, sehingga penyajian administrasi penjualan dan infromasi data lebih cepat dan akurat. Berangkat dari inilah penulis merancang aplikasi penjualan dan jasa service pada Showroom Expo Yamaha Motor Perdagangan Kabupaten Simalungun dengan harapan aplikasi penjualan dan jasa service dapat memberikan informasi yang cepat, tepat dan akurat.

Kata Kunci: Penjualan, Servis Sepeda Motor, Microsoft Visual Studio 2010, MySQL

\section{Pendahuluan}

Kota Perdagangan adalah ibukota Kecamatan Bandar, menurut sejarah tebentuknya Kota Perdagangan merupakan daerah pusat pemerintahan dari salah satu kerajaan yang berdiri yaitu Kerajaan Bandar. Kota ini terletak kurang lebih 40 $\mathrm{km}$ arah Timur dari ibukota Kabupaten Simalungun, Pematang Siantar dan 200 km dari Medan, ibukota Provinsi Sumatera Utara. Letaknya berada dekat dengan Sungai Bah Bolon, sebuah sungai yang berhulu di Simalungun melintasi Pematang Siantar dan bermuara di Selat Malaka, tepatnya di Kuala Tanjung Kabupaten Batu Bara. Melalui jalan darat, Kota Perdagangan terletak kira-kira di pertengahan jalan raya Pematang Siantar menuju kota Lima Puluh Kabupaten Asahan. Selain pusat pemerintahan kerajaan yang baru dan pemukiman penduduk. Kota perdagangan menjadi ramai dengan datang nya para pengusaha barat yang membocengi Hindia Belanda.

Rute lalu lintas kota Perdagangan sebagai ibukota distrik yang berada di tepi sungai bah bolon sekaligus sebagai pusat pemerintahan kerajaan baru, maka daerah ini dijadikan sebagai lokasi tempat tinggal penduduk namun dengan hadirnya pengusaha dari Hindia Belanda dengan membonceng pengusaha-pengusaha barat sehingga kota Perdagangan semakin lama kian ramai. Oeh Pemerintah Hindia Belanda kota Perdagangan dijadikan sebagai ibukota distrik Bandar karena posisinya di tepi sungai bah bolon karena sungai merupakan suatu rute lalu lintas utama termasuk dalam hal kegiatan eksport dan import. Pada awal abad ke 20 perkembangan perkebunan di kota Perdagangan sangat pesat sehingga pusat aktivitas penduduk di daerah ini tidak berkurang. Lalu lintas utama melalui 
sungai bah bolon mengalami perubahan rute menjadi jalur darat sehingga sangat berpengaruh terhadap rute lalu lintas sungai bah bolon. Pembangunan jalanjalan raya melalui jalur darat seperti pembangunan jalan raya dari Kota Pematangsiantar menuju Kota Lima puluh dan pembangunan jalur dan stasiun kereta api di Perlanaan (sekitar $20 \mathrm{~km}$ arah timur kota Perdagangan) salah satu stasiun kereta api kecil dengan rute Medan Tebing Tinggi - Tanjung balai dan Rantau Perapat sehingga jalur lalu lintas air sangat berkurang.

Berjalannya waktu dan berkembangnya ilmu pengetahuan teknologi khususnya dalam hal Komputerisasi Akuntansi dapat kita rasakan hampir di semua instansi baik di instansi pemerintah maupun swasta. Saat ini aplikasi yang dioperasikan oleh hampir seluruh sumber daya manusia suatu organisasi sehingga tidak dapat dipisahkan dengan operasi dan kehidupan organisasi. Berbagai jenis organisasi saat ini membutuhkan suatu aplikasi sistem informasi untuk mendukung proses bisnis, Showroom Expo Yamaha Motor di kota Perdagangan kabupaten Simalungun termasuk salah satunya.

Showroom Expo Yamaha Motor dalah sebuah dealer penjualan transportasi sepeda motor, suku cadang sekaligus yang memberikan jasa service. Showroom Expo Yamaha Motor masih belum menikmati akan teknologi yang kian menjamur untuk kegiatan industri otomotif, yang dimana di perusahaan tersebut masih menggunakan sistem yang manual untuk melayani para konsumen dan tidak efisein, sebagai contoh dalam proses pelayanan penjualan suku cadang motor yang terjadi saat ini belum cukup memberikan pelayanan yang memuaskan karena tidak adanya informasi yang cepat dan akurat bagi konsumen mengenai stok atau persediaan suku cadang motor yang tersedia. Sehingga konsumen yang datang sering sekali merasa kecewa karena sistem pelayanan penjualan yang relatif lama karena harus memeriksa persediaan suku cadang terlebih dahulu. Adapun masalah dalam pelayanan jasa service nya seperti sistem pelayanan yang masih menggunakan pencatatan manual dan belum adanya catatan atau bukti transaksi untuk konsumen. Banyaknya pelayanan jasa service sedikitnya 30 lebih pelanggan service dalam sehari, dimana para pelanggan harus datang langgung ke Showroom Expo Yamaha Motor di kota Perdagangan kabupaten Simalungun untuk mendaftarkan service motor yang akan memakan waktu, dimana para pelanggan datang untuk mengantri mendaftar service dan mengambil nomor antrian service, 
pelanggan banyak yang kecewa karena harus menunggu lama mendaftar dan mengambil nomor antriannya karena belum adanya sistem booking untuk konsumen disebabkan sistem yang berjalan di Showroom Expo Yamaha Motor di kota Perdagangan kabupaten Simalungun masih secara manual sudah seharusnya Showroom Expo Yamaha Motor memberikan yang terbaik dalam pelayanan kepada konsumen.

Selain itu masalah yang dihadapi Showroom Expo Yamaha Motor di kota Perdagangan kabupaten Simalungun sering mengalami kesulitan dalam pengontrolan stok barang masuk dan keluar yang dimana supplier resmi pusat cukup lama untuk mengetahui stok suku cadang apa saja yang sudah habis karena data yang di kelola banyak berupa sparepart dari berbagai tipe motor yamaha. Beberapa permasalahan diatas perusahaan berusaha melakukan atau meningkatkan kualitas pelayanan dengan membangunnya sistem informasi yang di rencanakan akan turut membantu dan memudahkan pelayanan yang lebih cepat, tepat dan akurat untuk kinerja perusahaan.

\section{Metode Penelitian}

Metode yang digunakan dalam penelitian ini:

\subsection{Sumber data}

a) Penulis menggunakan metode pengamatan (Observasi) pada Showroom Expo Yamaha Motor di kota Perdagangan Kabupaten Simalungun

b) Metode pengumpulan data dalam penelitian ini dilakukan dengan Studi pustaka untuk mencari teori dan konsep-konsep yang digunakan dalam penelitian sebagai landasan teori dalam penelitian, dan mencari metodologi yang akurat dan membandingkan antara teori yang ada dengan fakta yang ada di lapangan.

c) Data eksternal dalam penelitian ini merupakan data yang diperoleh dari media cetak, maupun informasiinformasi dari pihak lain

\subsection{Perancangan sistem}

a) Tahap Perancangan Basis Data Pada tahap perancangan basis data, tampilan perancangan penjualan dan jasa service berbasis Microsoft Visual Studio 2010 dan MySQL akan digambarkan dengan Entity Relation Diagram (ERD) pada gambar 1 dibawah ini: 


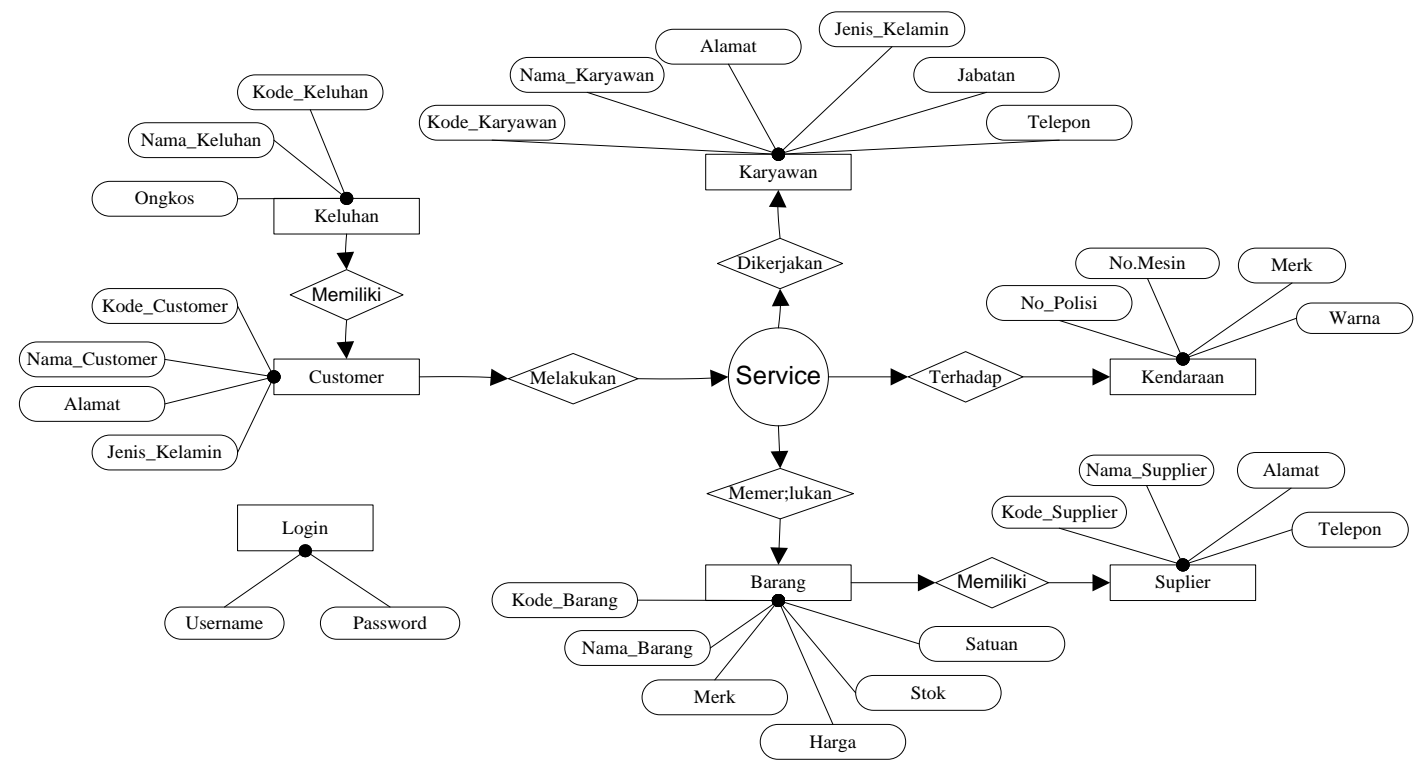

Gambar 1. Entity Relation Diagram (ERD) rancangan basis data penjualan dan jasa service

b) Tahap Rancangan Proses

Pada tahap perancangan basis data, tampilan penjualan dan jasa service berbasis Visual Studio dan

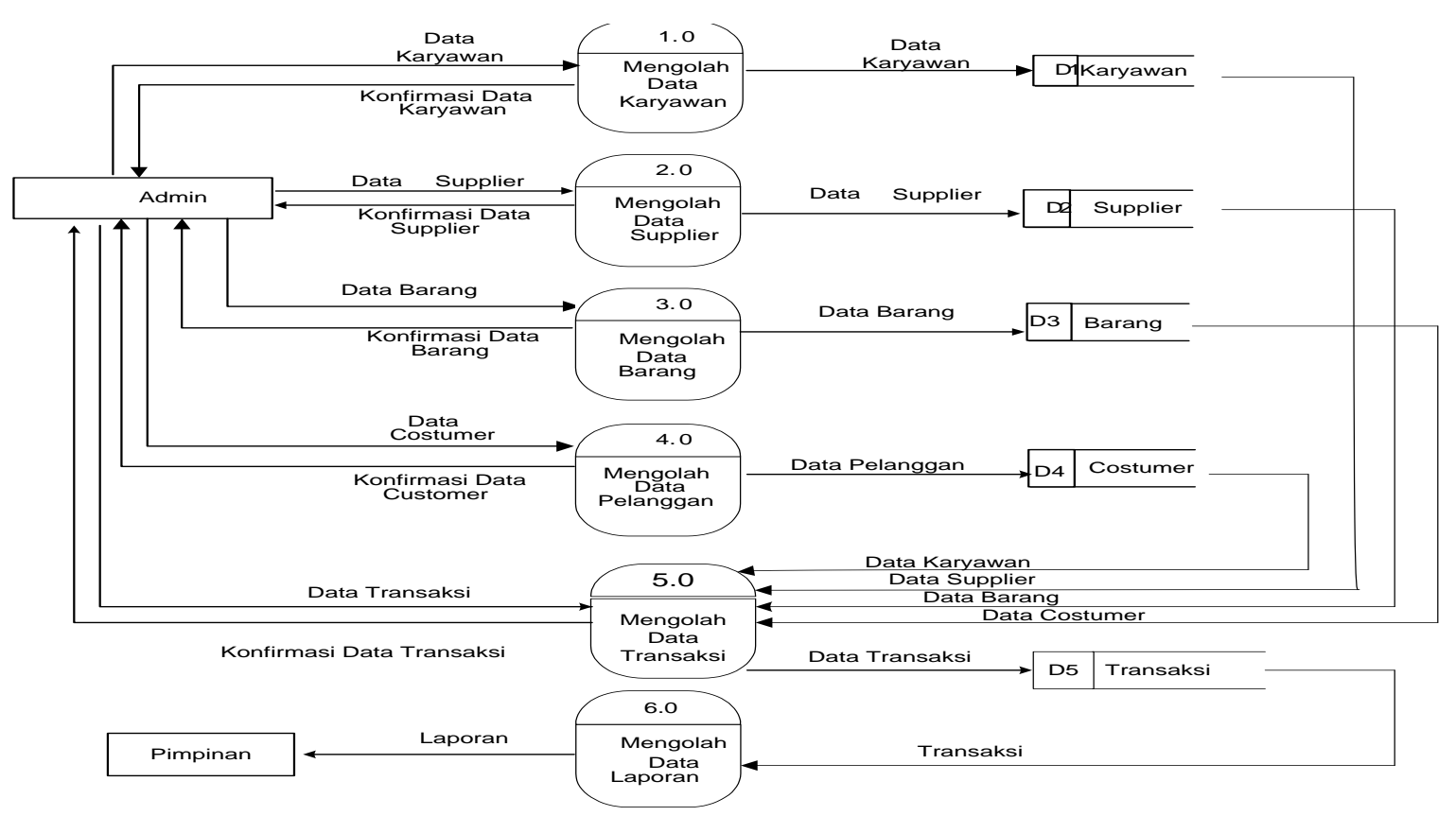

Gambar 2. Data Flow Diagram Rancangan Proses penjualan dan jasa service 


\section{Hasil dan Pembahasan}

\subsection{Tampilam Form Login}

Tampilan menu login merupakan tampilan yang pertama kali dilihat oleh pengguna, pada tahap ini user maupun admin melakukan proses login. Aplikasi ini hanya digunakan untuk satu user, yaitu admin yang mengelolah bagian penjualan dan jasa service.

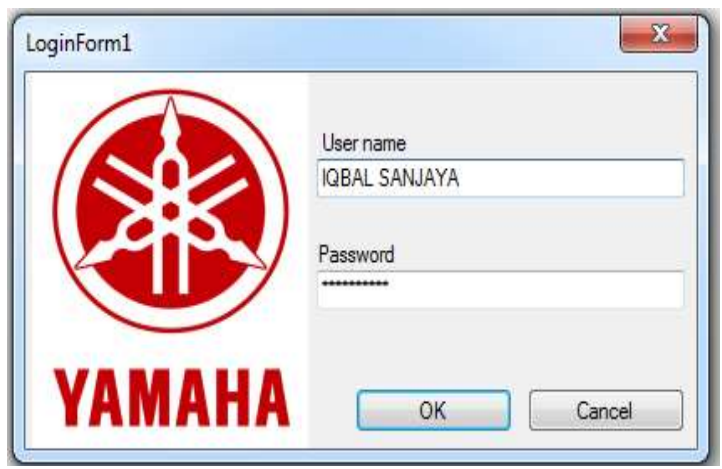

Gambar 3. Form login

\subsection{Tampilan Menu Utama}

Setelah user berhasil login selanjutnya user ke form menu utama, pada menu utama baik user maupun admin dapat menginput data-data yang ada dengan memilih beberapa menu-menu seperti yang ada pada gambar 4 berikut ini:

- Menu Master, isinya meliputi : barang, supplier, dan pegawai.

- Data Transaksi, isidnya meliputi : barang Masuk dan barang Keluar.

- Laporan, isinya meliputi : laporan barang Masuk dan laporan barang Keluar.

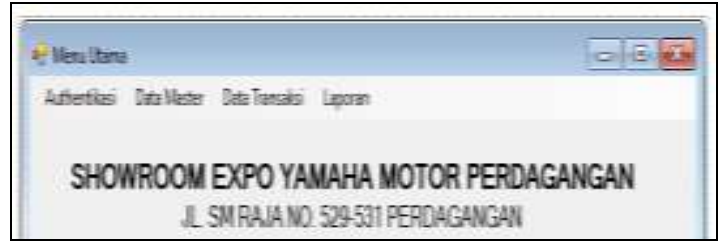

\section{Gambar 4. Form Menu Utama}

\subsection{Karyawan}

Pada from karyawan ini digunakan untuk memasukkan data-data karyawan, berikut ini gambar 5 merupakan tampilan dari form karyawan yang harus diinput.

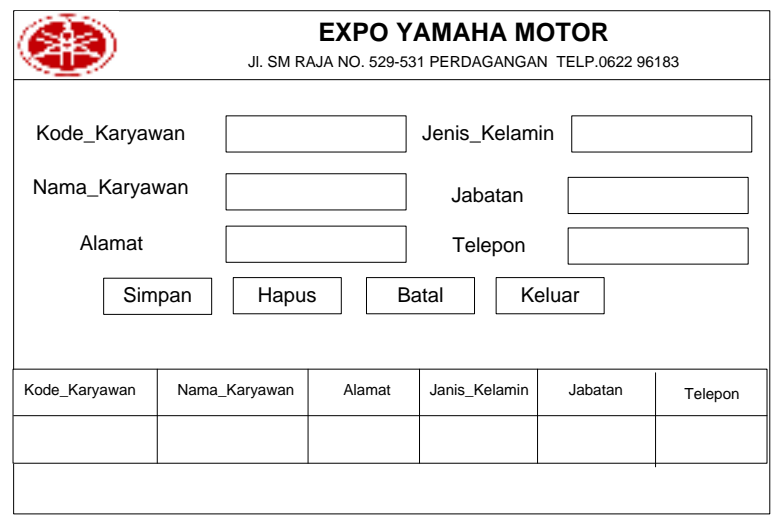

Gambar 5. Form Karyawan

\subsection{Customer}

Pada from customer ini digunakan untuk memasukkan data-data customer, gambar 6 berikut ini merupakan tampilan dari form customer yang harus diinput.

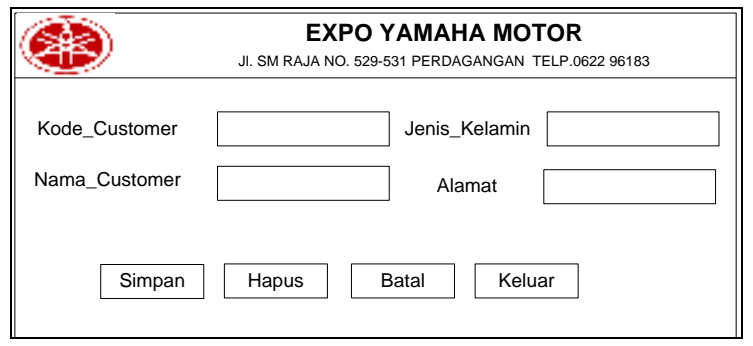

Gambar 6. Form Customer 


\subsection{Supplier}

Sama seperti sebelumnya, pada from supplier ini digunakan untuk memasukkan data-data supplier, gambar 7 berikut ini merupakan tampilan dari form supplier yang harus diinput.

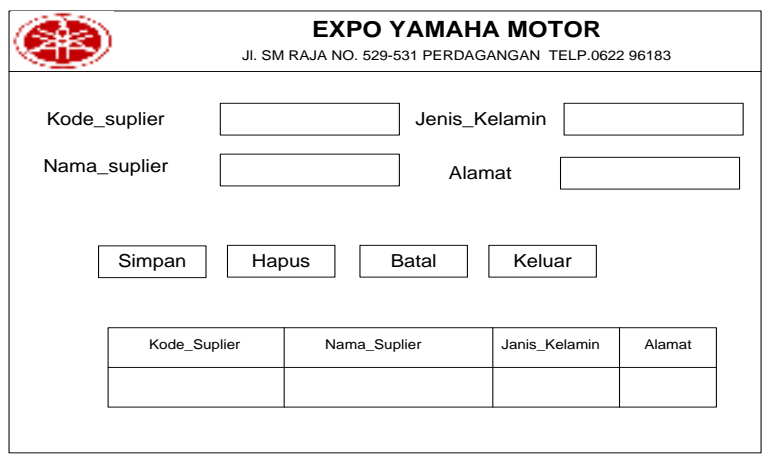

Gambar 7. Form supplier

\subsection{Barang}

Pada from barang ini digunakan untuk memasukkan data-data barang, gambar 8 berikut ini merupakan tampilan dari form barang yang harus diinput.

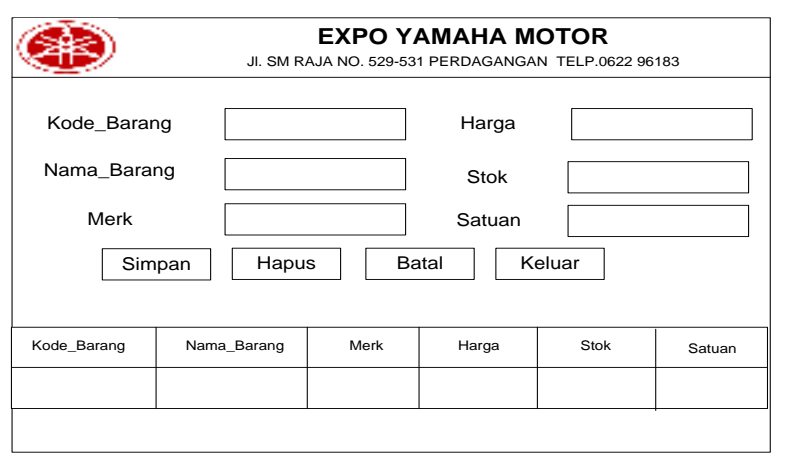

Gambar 8. Form barang

\subsection{Kendaraan}

Pada from kendaraan ini digunakan untuk memasukkan data-data kendaraan customer yang akan melakukan service sepeda motor, gambar 9 berikut ini merupakan tampilan dari form kendaraan yang melakukan service.

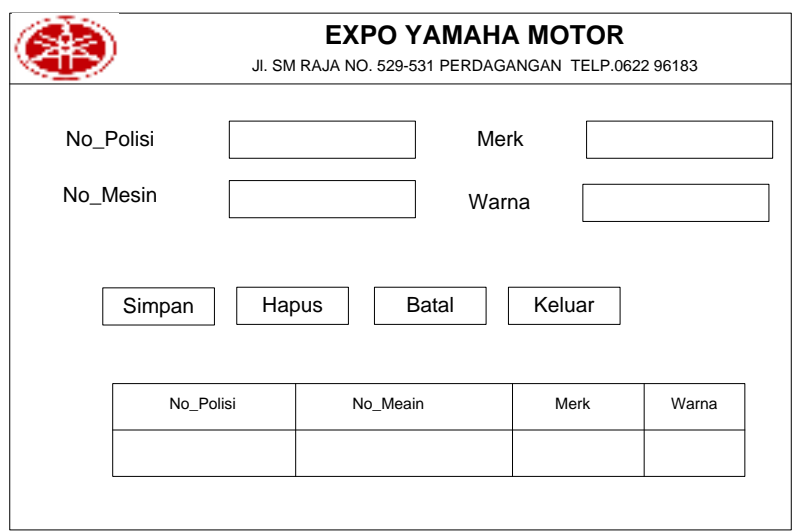

Gambar 9. Form Kendaraan

\subsection{Rancangan Keluaran (Output)}

Rancangan keluaran merupakan rancangan laporan yang akan dihasilkan oleh sistem yang dirancang. Gambar 9 dibawah ini adalah gambaran dari rancangan keluaran (Output) Shoroom Expo Yamaha Motor di kota Perdagangan Kabupaten Simalungun. Adapun rancangan keluaran (Output) ada pada gambar 9 berikut ini.

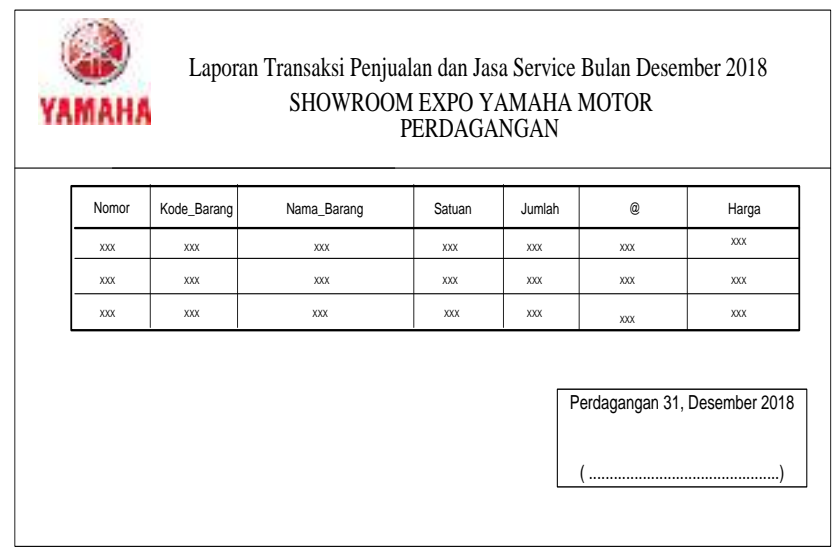

Gambar 9. Form Rancangan Keluaran 


\section{SIMPULAN}

Dari uraian dan pembahasan sebelumnya, dapat ditarik simpulan bahwa:

a) Rancang bangun penjualan dan jasa service pada Showroom Expo Motor Yamaha di kota Perdagangan kabupaten Simalungun ini dibuat dapat membantu manager maupun karyawan untuk menghasilkan output berupa laporan persediaan barang secara tepat dan dalam waktu yang singkat, sehingga dapat digunakan oleh karyawan dan manajer sebagai acuan dalam pengambilan keputusan.

b) Aplikasi ini dirancang menggunakan Microsoft visual studio 2010 dan MySQL, sehingga dapat mempermudah karyawan dan manajer untuk menganalisa laporan transaksi barang yang lebih detail terhadap arus barang, persediaan serta jasa service kendaraan sepeda motor

\section{DAFTAR PUSTAKA}

[1] Zulfiandri, S. Hidayatuloh, and M. Anas, "Rancang bangun aplikasi poliklinik gigi (studi kasus : poliklinik gigi kejaksaan agung ri)," in Depok: Universitas Gunadarma, 2014, vol. 8, no. Kommit, pp. 473-482.
[2] Yulica Wardany, D. Suhendro, and F. A. Purba, "Sistem Perhitungan PPH Pasal 21 Atas Pembayaran Gaji Pegawai Kantor pada PT. Perkebunan Nusantara III Sei Mangkei Kabupaten Simalungun," TECHSI, vol. 11, no. 1, pp. 157-168, 2019.

[3] I. S. Bahari, Dwiatmanto, and M. G. W. Endang, "Analisis Sistem Akuntansi Penjualan dan Penerimaan Kas dalam Upaya Peningkatan Pengendalian Intern (Studi pada PT Sumber Purnama Sakti Motor Lamongan)," J. Adm. Bisnis (JAB)|, vol. 53, no. 1, pp. 75-81, 2017.

[4] D. Suhendro, "Pengaruh Kualitas Sistem, Kualitas Informasi, Kualitas Pelayanan dan Ekspektasi Kinerja terhadap Kepuasan Pengguna dalam Penerapan Sistem Teknologi Informasi pada Koperasi di Kota Pematangsiantar," JURASIK (Jurnal Ris. Sist. Inf. Tek. Inform., vol. 1, no. 1, pp. 33-40, 2016.

[5] Herpendi, "Aplikasi Pengelolaan Nilai Akademik Mahasiswa dan DPNA ( Daftar Peserta dan Nilai Akhir )," $J$. Sains dan Teknol., vol. 2, no. 1, pp. 16, 2016.

[6] I. Lestari and H. Irawan, "Analisis dan Desain Electronic Customer 
Relationship Management (e- CRM)

Berbasis WEB Guna Membina serta

Meningkatkan Loyalitas Penyewa

Studi Kasus : PT Sari Indah Lestari

(SIL) - MALL CBD Ciledug," CKI

SPOT, vol. 10, no. 2, pp. 47-53, 2017.

[7] Irianto, S. Y. (2016). Penerapan Metode Fuzzy Inference System Tsukamoto Pada Sistem Pendukung Keputusan Untuk Penerimaan Beasiswa. Jurnal Informatika, 16(1), 10-23.

[8] R. 2014 Afyenni, "Perancangan Data Flow Diagram untuk Sistem Informasi Sekolah (Studi Kasus pada SMA Pembangunan Laboratorium UNP)," Teknoif, vol. 2, no. 1, pp. 35-39, 2014. 